\title{
Resistance and resilience to changing climate of Tuscany and Valpolicella wine grape growing regions in Italy
}

\author{
Maurizio Boselli ${ }^{1, a}$, Gianfranco Tempesta ${ }^{2}$, Monica Fiorilo ${ }^{3, \mathrm{~b}}$, and Michele Brandi ${ }^{4}$ \\ ${ }^{1}$ Università degli Studi di Verona, Dipartimento di Biotecnologie, Villa Lebrecht, via della Pieve 70, 37029 San Floriano (Province of \\ Verona), Italy \\ ${ }^{2}$ Vivaio Enotria, via Campagnole 2, 31050 Cavasagra di Vedelago (Province of Treviso), Italy \\ ${ }^{3}$ Web editor for "De Vulpe et Uva" \\ ${ }^{4}$ Marchesi Frescobaldi Societa’ Agricola S.r.l., via S. Spirito 11, 50125 Florence, Italy
}

\begin{abstract}
Global climate change poses new challenges for plant species, including new and complex combinations of environmental conditions to which plants should adjust and adapt. Mediterranean ecosystems are recognized biodiversity hotspots, but are also global climate change hotspots due to the concerted action of multiple environmental drivers. The Italian Peninsula presents a wide range of all these site-related elements influencing grapevine performance. From a climatic perspective, it delivers a relatively large set of mesoclimates, spanning from dryer regions, in the inner south, to more humid regions, in the northwest and northeast. Topography and soils are also quite distinct throughout the peninsula, ranging from extended flatland areas to steep mountainous regions, each with very different soil characteristics, which may influence crop selection and settlements in each region. All these elements are reflected in the different varieties grown throughout the peninsula.

This study aims to provide an improved assessment of the practical adaptation options for the viticulture of Tuscany and of Valpolicella and what could be the strength and resilience to climate change of grapevine varieties in these areas. According to the models tested, Italian viticulture is able to adapt better than other countries to global warming, as the placing at various altitudes up in the high hills and mountains sets off the mechanism called resilience.
\end{abstract}

\section{Introduction}

Of all drinks, wine is the only one with a symbolic value.

In Mediterranean Greco-Roman civilizations, where the Gods had a human appearance, there was a link between the natural and the divine.

The domestication of the Vitis genus with the obtaining of the vinifera species that occurred as described by the Old Testament in the Ararat region, irradiated from its cradle in the Pontus region to the Fertile Crescent and was then spread by the Greco-Roman civilisation. The Christian culture syncretically adopted the rituals.

The caravels and colonisation from the Mediterranean during the $16^{\text {th }}$ and $17^{\text {th }}$ centuries, took the Vitis vinifera to the New World.

Viticulture found favourable climate conditions and latitudes there, i.e. those that allow a full plant cycle of the vine, as it is a long-day plant. The photoperiod determines the hormonal cycle, the basis of the metabolic functions of the plant's rest period, budding, flowering, veraison and the accumulation of reserves for the subsequent cycle.

The historic vineyard areas, where viticulture has adapted, produce typical and famous wines.

New viticulture either refers to a historical and cultural heritage (viticulture taken to Serra Gaúcha from the Veneto) or to brands where the name of the variety prevails

\footnotetext{
a e-mail: maurizio.boselli@univr.it

b e-mail: www.devulpeetuva.com
}

(Chardonnay, Cabernet Sauvignon, Syrah, etc.), a mirror effect of the original historic areas (Bordeaux, Champagne and the Loire Valley).

The current prevalence of mass retail (80\% of wines are sold off-trade) concentrates on few wine types.

Therefore, the pedoclimatic indices reflect a reallocation policy of vineyard areas in parameters respecting the new styles of products requested by consumers.

An example of this is the relocation of Californian viticulture to Oregon and Australian viticulture to New Zealand.

For orographic reasons and the fact that it is a peninsula in the Mediterranean, which mitigates the extremities, Italy has restructured viticulture from polyculture that, with 2,046,000 hectares, covered the whole territory, while specialised viticulture numbered 1,142,000 hectares, concentrating in the more suitable areas with favourable pedoclimatic factors.

The affirmation of the DOCs started in the peninsula after the Second World War, giving legal certainty and trading recognition to historically deep-rooted products (Chianti, Valpolicella, Barolo, etc., etc.)

The legislator was generous when defining the areas, which are like XXL clothes (see attached maps). In other words, the vineyards can find space in potential DOC areas to move both to high ground and to areas better suited to respond not only to climate change but also to consumer tastes. 


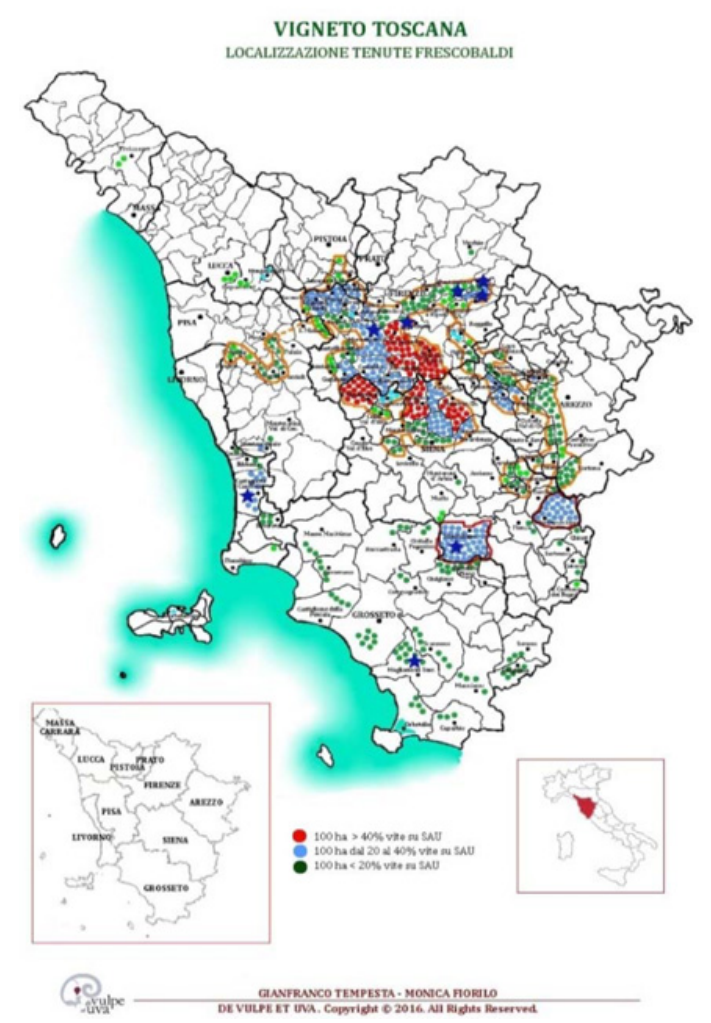

Figure 1. Location of the Marchesi de' Frescobaldi wineries in Tuscany indicated by a star.

It is certain that, from the Alps to the Strait of Sicily, there is an enormous variability within the pedoclimatic indices. We can find the same variability in the individual regions, as we will go on to demonstrate.

\section{The ability of traditional grape varieties to adapt to climate change}

Global climate change poses new challenges for plant species, including new and complex combinations of environmental conditions to which plants should adjust and adapt. The Mediterranean ecosystems are recognised elective places of biodiversity, but they are also hotspots for climate change due to the established action of several environmental variables. In the face of these changes, Mediterranean plants can migrate towards more suitable habitats, adapt through natural selection, adjust their phenotypic plasticity or die out.

The best-known vinegrowing regions in Italy have a long winemaking tradition and are considered to be of international importance. The adaptation of the wine grapevine to a warmer environment and reduced water is an important element for possible future cultivation in the context of sustainable vinegrowing practices. The wine grape varieties are traditionally grown in unique "terroirs" whose climate is a crucial component; the wine characteristics being directly linked to the climate of the region. A changing climate, therefore, is likely to modify both the style and the quality of the wine produced in a specific location.

The Italian peninsula has a vast range of elements linked to location which influence the performance of the vine. In fact, from a climatic point of view, Italy has an ample set of mesoclimates, ranging from dryer regions in the inland south, to the wetter regions in the northwest and northeast. Topography and soils are also very distinct throughout the peninsula, ranging from vast plains to steep mountainous regions, each with very different soil characteristics that may influence the spread and settlement of varieties. All of these elements are reflected in the different varieties grown throughout the peninsula.

To a certain extent, local varieties are an indirect manifestation of regional climate conditions. However, a multi-site study covering a vast range of different climates is needed to understand the heat requirements of varieties.

Furthermore, the concept of varietal plasticity should be considered, i.e. the ability to adapt to different climates $[1,2]$. Although heat requirements are specific to each variety [3-5], the same variety grown in different regions is able to show differences of up to $300^{\circ} \mathrm{C}$ (Degrees-Day) in Italy.

Climate change is expected to lead Italian vinegrowing to new challenges, i.e. a remodelling of the best varietal zones. Future forecasts highlight global warming and long periods of water stress in Italy [6], accompanied by an increase in the frequency of extreme weather events [7]. Climate change may move the phenological stages forward [8-11].

The grapes will ripen with decidedly higher environmental temperatures than in the past $[12,13]$, with negative consequences on wine quality, due to an imbalance of the organic components of the berry $[14,15]$.

\section{First case study: Tuscany}

The Renaissance originated in Tuscany in the $14^{\text {th }}$ century. During the same period, land was divided up into farms with sharecropping management.

The Alberata tree-trained vine landscape came about: the estate depended on the manor house, church or convent. The $16^{\text {th }}$ century saw the refeudalization of the countryside with large estates, new nobles and new middle classes.

The sharecropping system strengthened and was particularly suitable to the hills.

The Lorraine period modernised agriculture (Academy of Georgofili) with crop rotation and field preparation in the hills (Cosimo Ridolfi).

The system continued until 1950-1970 with the decline of sharecropping and the difficulty for other forms of management. The "farm" system remained but transformed into an economic management with salaried workers, abandoning polyculture for specialised viticulture, with few medium-sized and large wineries ( $>10$ ha), 1,185 wineries cover $59 \%$ of the surface area.

The model winery considered (Marchesi Frescobaldi) concentrates on the historical focus described and is present in all the DOC vinegrowing areas in Tuscany, therefore it is a statistical sample that proves the theories supported in this study. (Table 1).

The geological origin and the pedological matrix affect all the variables: The Apuan Alps (Carrara marble), the Volterra badlands; Sienese sandstone and the Mount Amiata lava dome are an example of this.

The altitude and geographical position give Tuscany different phytoclimatic areas. In some wineries such as 
Table 1. Vineyard surface area and Usable Agricultural Area (UAA) of the wineries owned by Marchesi Frescobaldi and their location [16] (for more statistical information: www . devulpeetuva.com).

\begin{tabular}{|c|c|c|c|c|c|c|c|c|c|c|c|c|c|c|}
\hline & \multicolumn{3}{|c|}{ MdF WINERY } & \multirow{2}{*}{\multicolumn{2}{|c|}{ MUNICIPALITY }} & \multicolumn{3}{|c|}{1990} & \multicolumn{3}{|c|}{2000} & \multicolumn{3}{|c|}{2010} \\
\hline & ha of vines & ha UAA & \% UAA & & & ha of vines & UAA & \% UAA & ha of vines & UAA & \% UAA & ha of vines & UAA & $\%$ UAA \\
\hline I COLLAZZI & 25.7 & 101.6 & 25 & Impruneta & $\mathrm{FL}$ & 476 & 2,580 & 18 & 285 & 1,900 & 15 & 241 & 1,751 & 14 \\
\hline NIPOZZANO & 318.9 & 408.1 & 78 & Pelago & $\mathrm{FL}$ & 351 & 1541 & 23 & 412 & 1.329 & 31 & 552 & 1.471 & 38 \\
\hline CAMPERITI & 65.3 & 96.1 & 68 & & & & & & & & & & & \\
\hline POMINO & 98.2 & 127.0 & 77 & Rufina & $\mathrm{FL}$ & 261 & 1,247 & 21 & 290 & 1,450 & 20 & 287 & 923 & 31 \\
\hline REMOLE & 11.6 & 95.5 & 12 & Pontassieve & $\mathrm{FL}$ & 845 & 5,145 & 16 & 728 & 4,282 & 17 & 485 & 3,382 & 14 \\
\hline CASTIGLIONI & 165.1 & 325.0 & 51 & Montespertoli & $\mathrm{FL}$ & 2,009 & 7,833 & 26 & 1,975 & 7,315 & 27 & 2,047 & 6,376 & 32 \\
\hline CASTELGIOCONDO & 274.0 & 340.3 & 81 & Montalcino & $\mathrm{SI}$ & 2,130 & 13,444 & 16 & 2,924 & 11,696 & 25 & 3,974 & 11,531 & 34 \\
\hline AMMIRAGLIA & 143.5 & 180.8 & 79 & Magliano in Toscana & $\mathrm{GR}$ & 485 & 15,035 & 3 & 617 & 15,425 & 4 & 994 & 13,856 & 7 \\
\hline ORNELLAIA & 131.9 & 146.6 & 90 & Castagneto Carducci & LI & 375 & 6,478 & 6 & 592 & 4,933 & 12 & 1,029 & 4,680 & 22 \\
\hline Vigneti di NUGOLA & 96.1 & 101.2 & 95 & Colle Salvetti & LI & 206 & 4,120 & 5 & 111 & 4,269 & 3 & 66 & 4,292 & 2 \\
\hline \multirow[t]{2}{*}{ CORTE } & 10.5 & 226.0 & 5 & Borgo San Lorenzo & $\mathrm{FL}$ & 134 & 5,690 & 2 & 110 & 5,500 & 2 & 60 & 5,000 & 27 \\
\hline & $1,340.9$ & $2,148.1$ & 62 & & & 7,272 & 63,113 & 12 & 8,044 & 58,100 & 14 & 9,735 & 53,262 & 18 \\
\hline (-) TUSCANY & & & & & & 70,900 & & & 58,170 & & & 59,839 & & \\
\hline FRIULI : ATTEMS & 32.2 & 35.5 & 91 & Gorizia (Lucinico) & GO & 291 & 1,164 & 25 & 264 & 644 & 41 & 306 & 588 & 52 \\
\hline
\end{tabular}

Table 2. Altitude variation in the Tuscan wineries considered.

MORPHOMETRIC ZONING

\begin{tabular}{|c|c|c|c|c|c|c|c|c|c|c|c|c|c|c|}
\hline \multirow{2}{*}{ MdF WINERY } & \multirow{2}{*}{\multicolumn{2}{|c|}{ MUNICIPALITY }} & \multirow{2}{*}{$\begin{array}{c}\text { MORPHOMETRIC } \\
\text { INTENSITY }\end{array}$} & \multicolumn{4}{|c|}{ INTENSITY OF ELEVATION (m) } & \multicolumn{3}{|c|}{ ALTITUDE (m) } & \multicolumn{4}{|c|}{ SLOPE (degrees) } \\
\hline & & & & $0-20$ & $21-125$ & $126-250$ & $251-1000$ & $<201$ & $201-600$ & $>600$ & $0-3$ & $4-15$ & $16-23$ & $>24$ \\
\hline I COLLAZZI & Impruneta & $\mathrm{FL}$ & 33.9 & & 95.1 & 4.9 & & 63.2 & 36.8 & & 11.1 & 77.9 & 8.1 & 2.9 \\
\hline NIPOZZANO & Pelago & $\mathrm{FL}$ & 53.1 & & 27.0 & 61.3 & 11.7 & 13.5 & 53.7 & 32.8 & 6.5 & 63.6 & 18.5 & 11.4 \\
\hline POMINO & Rufina & $\mathrm{FL}$ & 57.3 & & 13.6 & 68.9 & 17.5 & 17.8 & 48.6 & 33.6 & 6.6 & 49.7 & 24.1 & 19.6 \\
\hline REMOLE & Pontassieve & $\mathrm{FL}$ & 50.8 & & 16.6 & 68.5 & 14.9 & 19.5 & 68.4 & 12.1 & 5.5 & 56.9 & 20.8 & 16.8 \\
\hline CASTIGLIONI & Montes pertoli & $\mathrm{FL}$ & 34.3 & 0.1 & 86.7 & 13.2 & & 73.4 & 26.6 & & 16.4 & 65.3 & 14.7 & 3.6 \\
\hline CASTELGIOCONDO & Montalcino & $\mathrm{SI}$ & 33.9 & 1.6 & 74.9 & 23.1 & 0.3 & 28.9 & 70.2 & 0.9 & 21.0 & 64.1 & 11.5 & 3.5 \\
\hline L'AMMIRAGLIA & Magliano in Toscana & $\mathrm{GR}$ & 27.8 & 3.8 & 86.8 & 8.8 & 0.6 & 79.6 & 20.4 & & 32.2 & 55.3 & 10.4 & 2.1 \\
\hline ORNELLAIA & Castagneto Carducci & LI & 23.3 & 37.9 & 36.5 & 24.2 & 1.3 & 77.4 & 22.6 & & 50.7 & 29.6 & 11.9 & 7.8 \\
\hline NUGOLA & Collesalvetti & LI & 18.7 & 39.5 & 49.1 & 11.2 & 0.1 & 91.0 & 9.0 & & 52.4 & 35.7 & 9.0 & 3.0 \\
\hline
\end{tabular}

Table 3. Variation of the bioclimatic indices of Huglin and Winkler in the Marchesi Frescobaldi wineries.

\begin{tabular}{|c|c|c|c|c|c|c|c|c|c|c|c|c|c|c|c|c|c|c|}
\hline & \multicolumn{9}{|c|}{ HUGLIN } & \multicolumn{9}{|c|}{ WINKLER } \\
\hline & 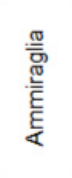 & 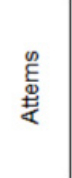 & 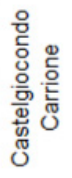 & 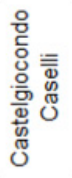 & 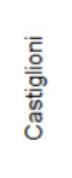 & 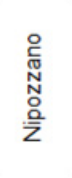 & $\begin{array}{l}\frac{\pi}{\mathrm{o}} \\
\frac{\mathrm{O}}{\mathrm{z}}\end{array}$ & 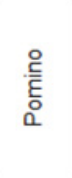 & 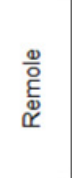 & 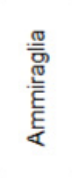 & $\begin{array}{l}\stackrel{\mathscr{E}}{E} \\
\text { 焉 }\end{array}$ & 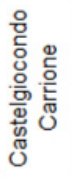 & 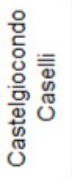 & 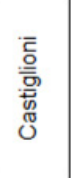 & 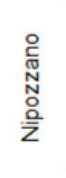 & $\begin{array}{l}\frac{\pi}{0} \\
\frac{\mathrm{O}}{2}\end{array}$ & 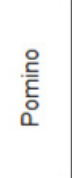 & 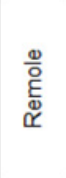 \\
\hline Storico & 2655 & 2247 & 2569 & 2425 & 2659 & 2343 & 2469 & 2017 & 2547 & 2141 & 1787 & 2060 & 1937 & 2135 & 1889 & 2035 & 1561 & 2006 \\
\hline 2011 & 2779 & & 2615 & 2442 & 2591 & 2400 & 2479 & 2009 & 2643 & 2254 & & 2034 & 1896 & 2057 & 1892 & 1994 & 1520 & 2022 \\
\hline 2012 & 2676 & & 2688 & 2572 & 2671 & 2457 & 2455 & 2021 & 2636 & 2193 & & 2165 & 2060 & 2167 & 2026 & 2022 & 1583 & 2161 \\
\hline 2013 & 2742 & & 2458 & 2410 & 2626 & 2286 & 2461 & 2074 & 2313 & 2239 & & 1978 & 1967 & 2090 & 1825 & 2058 & 1641 & 1821 \\
\hline 2014 & 2460 & 2163 & 2388 & 2187 & 2557 & 2210 & 2358 & 1887 & 2510 & 1956 & 1721 & 1942 & 1753 & 2079 & 1813 & 1992 & 1474 & 1979 \\
\hline 2015 & 2617 & 2332 & 2697 & 2517 & 2851 & 2365 & 2591 & 2095 & 2632 & 2065 & 1853 & 2180 & 2008 & 2282 & 1890 & 2110 & 1587 & 2047 \\
\hline
\end{tabular}

Nipozzano, Pomino, Castelgiocondo and to a lesser extent Remole, the variations in altitude within the wineries may allow vinegrowing to be elevated, so it could benefit from lower degree days (Table 2).

Rainfall and temperature confirm what has been affirmed above, pointing out that Tuscan viticulture does not use irrigation, hence the variable of production volume is conditioned by rainfall.

The bioclimatic indices originating from different parameters considered, give a clear demonstration of the extreme variability of the different Tuscan areas (Table 3) with important differences particularly between Pomino (Rufina) and Castiglioni (Montespertoli).
The variation of the environmental characteristics observed throughout Tuscany protects from the danger of reducing viticulture due to ongoing climate change. In fact, due to the flexibility allowed by current production regulations that allow an elevation of viticulture also to high altitudes (500-600 $\mathrm{m}$ above sea level), the possibility of growing traditional Italian varieties will be safeguarded.

\section{Second case study: Valpolicella}

The description of vinegrowing methods in Valpolicella began in the Early Middle Ages when the term "terra cum vineis" was coined, indicating an area where vines where 


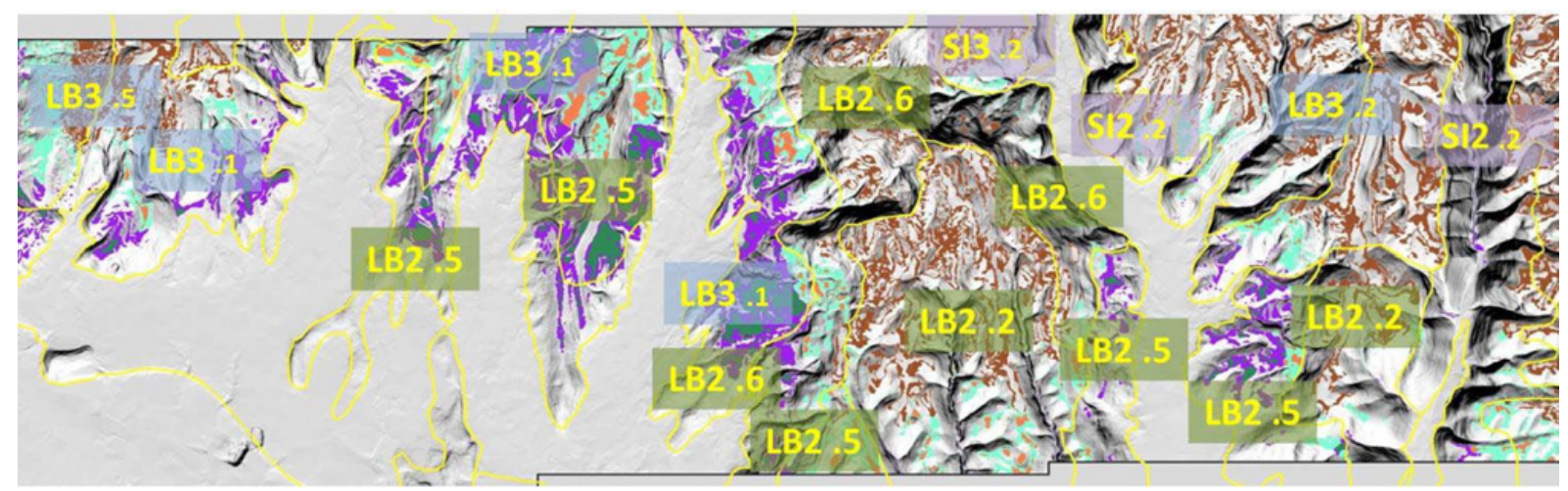

Figure 2. Classes of altitude-slope suitability on shaded relief of the elevation in the Valpolicella area under study and the main types of soil from the regional soil map.

grown: it could be made up of the "low vineyard", grown in the hills and the "high vineyard", grown in the plain.

The latter stood out for the type of support used, which could be a simple stake (dead support) or a plant (live support).

In around the 1400s, the "piantata" spread through the Verona plains"; rows of vines trained on live supports interspersed with cereal crops.

Abbot Bartolomeo Lorenzi wrote some important agronomical writings after his retreat to the house in Mazzurega, in Valpolicella, where he spoke, among other things, of choices of grape varieties, planting period, fertilizing, supports, green harvest and looking after the soil.

At the start of the 1800 s, several academics at the Academy of Agriculture, Science, Letters and Arts in Verona devoted themselves to describing 80 varieties of red and white grapes grown in the province.

The use of the most important varieties in Valpolicella certainly has ancient origins. The Corvina and Corvinone varieties, coming under the varietal group generally called Corve or Corbe, had been used since ancient times. The name Corbina (or Corba) is mentioned by Prof. Domizio Cavazza in the volume "Viticoltura", which was part of the New Italian Agricultural Encyclopaedia (published by UTET, Turin, 1914).

For a few years now, vinegrowers in Valpolicella have chosen the highest altitudes to produce their grapes and wines.

The influence of the nearby Lake Garda is clear, especially the mild climate, but also the rise in average temperatures that often force early harvests.

For this reason, a study has been started to estimate how much vineyard surface area can be potentially invested in high hills, while taking into account some basic requirements for rational farming and for pedoclimatic characteristics in keeping with the production of the maximum possible quality.

\section{Map databases used}

During this study, the following digital map databases were used from the map archive of the Veneto region:

1. Regional DTM with cells of 5 metre sides in ASCII format, with map specifications relative to the sections of the CTR (Technical Regional Map)
Table 4. Values of the Winkler scale (GDD) per altitude-slope class of suitability - Valpolicella (average values for the years 2008-2009-2010-2011-2012).

\begin{tabular}{|l|l|l|l|}
\hline $\begin{array}{l}\text { slope } \\
\text { altitude }\end{array}$ & $0-10 \%$ & $10-20 \%$ & $15-25 \%$ \\
\hline $200-300 m$ & 1958 & 2036 & - \\
\hline $300-400 m$ & 1875 & 1891 & - \\
\hline$>400 m$ & - & - & 1735 \\
\hline
\end{tabular}

made by the CNR (National Research Council) in Pisa through the generation of the TIN, starting from contour lines and spot heights deduced by the CTRN.

2. Soil map of the Veneto, containing the soil typological units and the description of the map units in shapefile vector format.

The values of the Winkler scale have been calculated according to the model provided by Boselli et al. [17], which is based on data processing on an orographic and topographic basis (altitude, relative position on the slope distance from the bottom and the ridge - main exposure of the slope and size of the valley). Depending on the heat requirements of the Corvina variety (1800-1850 GDD), the highest areas may cause excessively late ripening with difficulty in reaching a sufficient potential alcohol content, especially in the more unfavourable vintages from a climate point of view.

The ability of the Corvinone variety to adapt seems to be better.

Figure 2 shows the various types of soil that characterise the upper Valpolicella and are compatible with quality viticulture:

LB1 = Soils on low ridges with a basaltic substratum and slopes modelled mainly in ledges and very anthropized.

LB2 = Soils on plateaus and long ridges with low slopes enclosed by steep, short escarpments, on limestone.

LB3 = Soils on plateaus and long ridges in calcareous marl (more rarely in hard limestone and dolomite rock) highly undulated with rounded forms.

SI2 $=$ Soils on valley cuts and escarpments in hard limestone with moderately steep slopes.

SI3 = Soils on valley cuts, escarpments, small basins in calcareous marl (Biancone) with regular rounded steep slopes. 


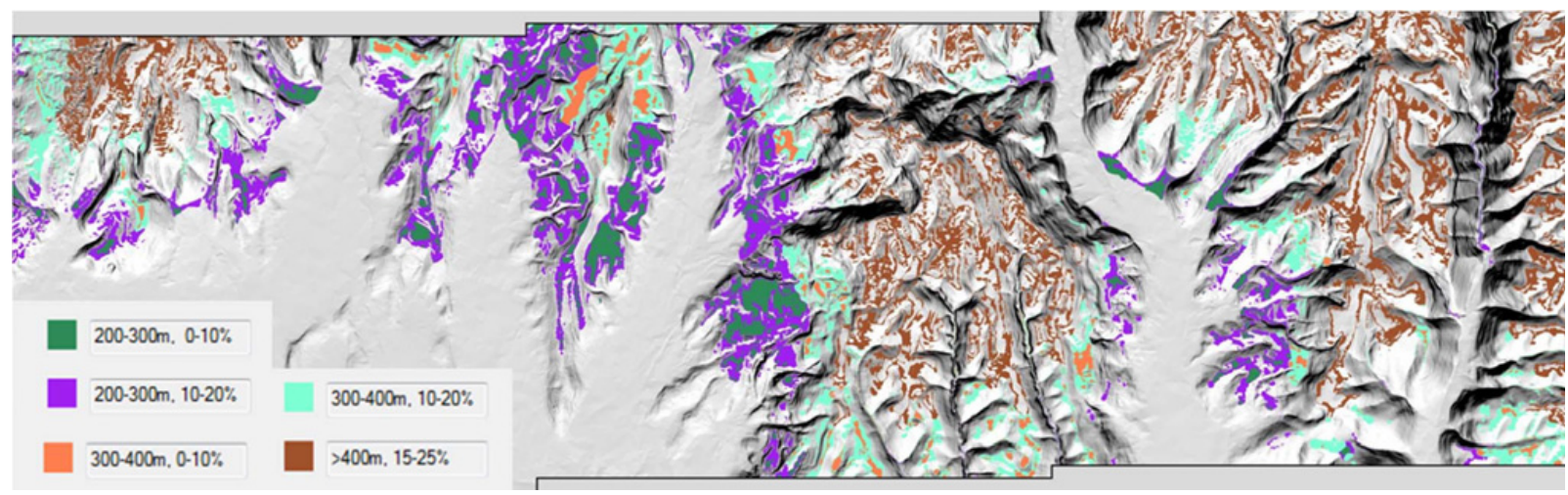

Figure 3. Classes of altitude-slope suitability specific for the variety on shaded relief of the Valpolicella area under study.

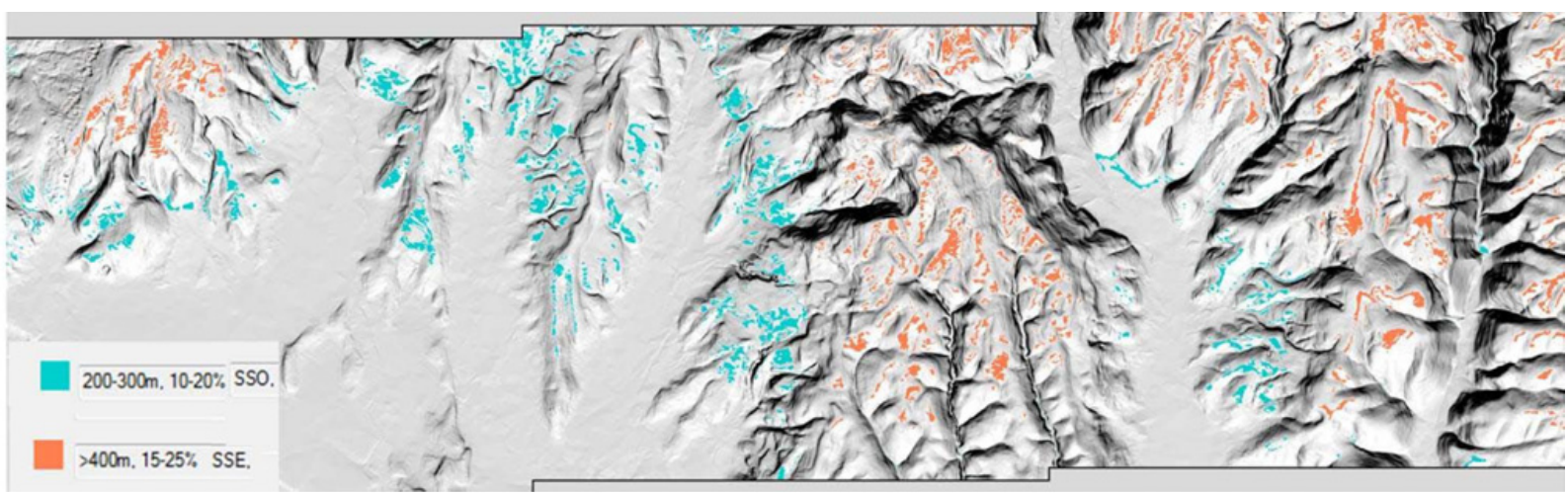

Figure 4. Classes of altitude-slope-exposure suitability specific for the variety on shaded relief of the elevation in the Valpolicella area under study.

These soils have very different characteristics but are all suitable to viticulture aimed at quality products. They are often highly calcareous soils, which limit vigour and productivity to favour maximum quality.

Figure 3 shows the different-coloured areas that could potentially be planted with vines. Particularly for the Corvina variety, if it is elevated to higher altitudes, it must be planted in the best exposures.

Considering the distribution of slopes of the altitudeslope classes in the Valpolicella area under study, the analysis of the two classes with most hectares $(200-300 \mathrm{~m} / 10-20 \%$ and $>400 \mathrm{~m} / 15-25 \%)$ has been extended to the exposure of the slopes considering an optimum south/southwest exposure (aspect between $157^{\circ}$ and $247^{\circ}$ ) for the $200-300 \mathrm{~m} / 10-20 \%$ class and south/southeast (aspect between $113^{\circ}$ and $203^{\circ}$ ) for the $>400 \mathrm{~m} / 15-25 \%$ class. Only considering the slopes with a south/southeast exposure, the number of hectares for the $>400 \mathrm{~m} / 15-25 \%$ altitude-slope class passes from 769 ha to 294 ha, whereas only considering the slopes facing south/southwest, the number of hectares of the 200-300 m/10-20\% altitude-slope class drops from 535 ha to 219 ha.

\section{Conclusions}

Italian viticulture, according to the models tested, has the ability to adapt itself better than other countries to global warming, being able to vary cultivation altitudes up to high hills and mountains, setting off a mechanism called resilience. Moreover, the results indicate that Italian varieties have a higher capacity to adapt, because they have grown in a wide interval of heat conditions through time. The study has provided the basic knowledge needed to justify vinegrowing in those areas and has formulated the possibilities of extending viticulture from the current areas to other currently unused ones.

As well as providing a valid answer to climate change and increasing the intrinsic quality of the product, moving viticulture to hilly areas is a factor of primary importance for maintaining agroecological biodiversity, soil preservation and, above all, for tackling hydrogeological instability.

\section{References}

[1] V.O. Sadras, M.P. Reynolds, A.J. de la Vega, P.R. Petrie, R. Robinson R., Field Crops Res., 110 (3): 242-250 (2009)

[2] A. Caffarra., E. Eccel, Int. J. Biometeorol., 54 (3): 255-267 (2010)

[3] J. Lopes, J.E. Eiras-Dias, F. Abreu, P. Climaco, J.P. Cunha, J. Silvestre, Ciência Téc. Vitiv., 23 (1): 61-71 (2008)

[4] I.G. de Cortazar-Atauri, N. Brisson, J.P. Gaudillere, Int. J. Biometeorol., 53 (4): 317-326 (2009)

[5] B. Kose, S. Afr. J. Enol. Vitic., 35 (1): 90-102 (2014)

[6] G.V. Jones, F. Alves, Int. J. Glob. Warming, 4 (3/4): 383-406 (2012)

[7] C. Andrade, H. Fraga, J.A. Santos, Sci. Lett., 15 (2): 149-156 (2014)

[8] M. Moriondo, M. Bindi, Ital. J. Agrometeorol., 3: 5-12 (2007) 
[9] E. Duchene, F. Huard, V. Dumas, C. Schneider, D. Merdinoglu, Clim. Res., 41 (3): 193-204 (2010)

[10] A. Menzel, H. Seifert, N. Estrella, Int. J. Biometeorol., 55 (6): 921-932 (2011)

[11] M. Ruml, A. Vukovic, M. Vujadinovic, V. Djurdjevic, Z. Rankovic-Vasic, Z. Atanackovic, B. Sivcev, N. Markovic, S. Matijasevic, N. Petrovic, Agric. For. Meteorol., 158: 53-62 (2012)

[12] I. Chuine, K. Kramer, H. Hanninen, In Phenology - An Integrative Environmental Science, Tasks for Vegetation Science, Vol. 39, M.D. Schwartz (ed) (Kluwer Acad. Pub., London: 217-235, 2003)

[13] A. Bock, T. Sparks, N. Estrella, A. Menzel, Clim. Res., 50 (1): 69-81 (2011)
[14] L. Hannah, P.R. Roehrdanz, M. Ikegami, A.V. Shepard, M.R. Shaw, G. Tabor, L. Zhi, P.A. Marquet, R.J. Hijmans, Proc. Natl. Acad. Sci. USA, 110 (17): 6907-6912 (2013)

[15] H. Fraga, A.C. Malheiro, J. Moutinho-Pereira, J.A. Santos, Agric. For. Meteorol., 185: 26-36 (2014)

[16] G. Tempesta, M. Fiorilo, M. Marenghi, Vigneto Italia: stato attuale, movimenti e tendenze. Cosa succede nel "Paese del Vino" (Millevigne, Ed. Wine Pass, Alba, Italia, 2014)

[17] M. Boselli, A. Pasquali., F. Zinoni, P. Lega, Caratterizzazione del territorio dell'Emilia Romagna mediante l'uso di indici bioclimatici (Atti Convegno: Agrometeorologia per un servizio regionale. Perugia: 127-140, 1991) 